\title{
Precipitating Cloud Characteristics during Changma as Seen in TRMM PR Observations
}

\author{
Eun-Kyoung Seo ${ }^{1}$ and Kyu-Myong Kim² \\ ${ }^{1}$ Department of Earth Science Education, Kongju National University, Kongju 314-701, Republic of Korea \\ ${ }^{2}$ Climate and Radiation Laboratory, NASA's Goddard Space Flight Center, Greenbelt, MD, USA
}

Correspondence should be addressed to Eun-Kyoung Seo; ekseo@kongju.ac.kr

Received 9 January 2017; Revised 7 May 2017; Accepted 15 May 2017; Published 20 June 2017

Academic Editor: Roberto Fraile

Copyright ( 2017 Eun-Kyoung Seo and Kyu-Myong Kim. This is an open access article distributed under the Creative Commons Attribution License, which permits unrestricted use, distribution, and reproduction in any medium, provided the original work is properly cited.

\begin{abstract}
The climatological characteristics of precipitating clouds during Changma, the summer rainy period in the Korean Peninsula, were investigated using the Precipitation Radar (PR) on the Tropical Rainfall Measuring Mission (TRMM) satellite. This investigation was further augmented with reanalysis data. Specifically, Changma clouds are compared with post-Changma clouds. Similarities and differences in cloud properties between the two periods are discussed based on seasonal changes in thermodynamic environments. For convective clouds migrating along the Changma (stationary) front, rain intensity is much stronger and cloud height is relatively higher than during any other summer period, including post-Changma period. Convective rain clouds have a large seasonal variability, even during summer. The seasonal variability in rain parameters related to convective rain type appears to be due to the thermodynamic and dynamic environments.
\end{abstract}

\section{Introduction}

Changma, a summertime monsoon phenomenon over the Korean Peninsula, brings considerable socioeconomic impact to many parts of Korean society every year. Climatologically, the Changma season spans late June through late July. During that period, Koreans endure harsh weather conditions of humid air and fairly frequent and prolonged rainfall events. About half of the annual rainfall events over Korea occur during the Changma, bringing more than half of the total annual rainfall as well. Changma's climatological tendency of bringing most of the nation's annual rainfall in a relatively short time intensifies the challenge of distributing water usage evenly during the year. Even more seriously, intense Changma rainfall sometimes threatens lives and property throughout the country. About half of the extreme rain events during Changma are associated with large amount of moisture fluxes from the south, when the subtropical high intensifies and expands westward $[1,2]$. Therefore, Changma has long interested atmospheric scientists and hydrologists in Korea.
Previous studies examined Changma onset [3, 4], development mechanisms [5], the role of the North Pacific high pressure $[2,6-8]$, interannual variability of rainfall [9-14], and long-term climatological evolution [15-17]. The main focuses have been the dynamic and thermodynamic atmospheric environment of Changma, relying on reanalysis grid data and conventional observations. Much is known about the large-scale forcing, but there still remain questions about physical properties of raining clouds during Changma precipitation. Further studies have become possible as various satellite observations have developed and become available to researchers. For example, satellite IR image data are used to investigate the physical properties of Changma clouds and precipitation [18-20]. The Precipitation Radar (PR) instrument and Tropical Rainfall Measuring Mission (TRMM) Microwave Imager (TMI) of TRMM satellite from space provides a very unique data set for clouds, which complement the conventional observations from the Earth's surface [21, 22]. In particular, the PR radar offers rain intensity measurements, three-dimensional cloud structures, rain types, and cloud top heights over not only land but also ocean [23-25]. 
This study first inquires how raining clouds during the Changma period, which have the distinct properties of having a stationary front in large scale, differ from summer rainfall clouds in non-Changma periods. It investigates the characteristics of raining Changma clouds with TRMM PR observations. It seeks insights and multilateral perspectives into rainfall characteristics of Changma by comparing and contrasting the mean properties of satellite-observed Changma clouds with those of post-Changma clouds over the course of Korean summertime. Meteorological environments for the two periods are also examined using reanalysis data. This will further reveal how the characteristic features of Changma precipitation around the Korean Peninsula are connected to the geophysical environments.

Two separate data sets spanning 16 years from 1998 to 2013 were gathered from National Aeronautics and Space Administration (NASA) TRMM PR observations and reanalysis data. Each provides data for the Changma and postChangma periods over the study region, respectively. The data analysis will present long-term averaged properties rather than short-period snapshots. Section 2 summarizes details of the data and analysis. Section 3 examines the various properties of clouds. Sections 4 and 5 examine the dynamic and thermodynamic variables in synoptic-scale environments, respectively, with the help of reanalysis data. Lastly, conclusions are provided.

\section{Data}

This study uses TRMM PR observations and Modern-Era Retrospective analysis for Research and Applications (MERRA) reanalysis data. PR provides vertical structure and rain type of raining clouds, which is especially valuable in examining characteristics of raining clouds over ocean during Changma and post-Changma periods. Meanwhile, MERRA provides geophysical variables for large-scale environments of Changma and post-Changma period. More detailed descriptions follow in the subsequent sections of this paper.

2.1. PR Observational Data. This study uses level 2 data from TRMM PR version 7 products. Specifically, it uses radar reflectivity (2A25) and rain type (2A23) during the summer months of June, July, and August from 1998 to 2013 over the East Asian region $\left(10^{\circ} \mathrm{N}-40^{\circ} \mathrm{N}, 122^{\circ} \mathrm{E}-134^{\circ} \mathrm{E}\right)$. The PR is a cross-track scanning radar operated at $13.8 \mathrm{GHz}$ [26]. Its sensitivity is about $17 \mathrm{dBZ}$ which corresponds to about $0.7 \mathrm{~mm} \mathrm{~h}$ in rain rate. The PR pixels have a horizontal resolution of $4.3 \mathrm{~km}$ at nadir and a vertical resolution of $250 \mathrm{~m}$ from the Earth's surface to $20 \mathrm{~km}$ in altitude. The radar reflectivities were corrected for attenuation using HitschfeldBordan formulation and an alpha-adjustment technique which incorporates information from a surface reference $[26,27]$. Radar-observed rain profiles are categorized into three types: stratiform, convective, and others [28]. The category "others" is excluded in this study since it has a small population size. Thus, the TRMM PR observations provide vertical structures and rain types of raining clouds over both land and ocean. These are particularly useful in characterizing raining clouds.

2.2. MERRA Reanalysis Data. MERRA [29] is a NASA reanalysis for the satellite era using the Goddard Earth Observing System Data Assimilation System Version 5 (GEOS-5) [30]. It covers the modern era of remotely sensed data, from 1979 through 2015, with special focus on the hydrological cycle. Like similar reanalyses, MERRA provides meteorological parameters (winds, temperature, and humidity) and other diagnostics such as fluxes at the surface and the top of the atmosphere, diabetic terms, and observational corrections imposed by the data assimilation procedure. Spatial resolution is globally $0.625^{\circ} \times 0.5^{\circ}$ longitude by latitude. However, this study uses 3 -hourly data at coarser grids $\left(1.25^{\circ} \times 1.25^{\circ}\right.$ longitude by latitude, 42 vertical levels $)$ when calculating Convective Available Potential Energy (CAPE) and Convective Inhibition (CIN).

2.3. Definition of Changma and Post-Changma Periods. Summer monsoon rainy seasons in East Asia (Meiyu, Baiu, and Changma) are associated with the northward migration of the East Asian Summer Monsoon, which has been seen as a local manifestation of a northward-propagating climatological intraseasonal oscillation [31, 32]. In Korea, the rainy season, Changma, begins late June and ends late July. According to a recent study [3], the climatological onset is on June 1920 , and the retreat is on July 20-21 near Jeju Island in the southernmost part of Korea. Onset occurs on June 24-25 and retreat on July 24-25 in the middle of the Korean Peninsula.

Climatologically, a dry period precedes the onset of Changma. During this long dry period starting mid-May, mean anticyclone located to the west of the Korean Peninsula prevents moisture transport from the south China Sea [33], resulting in a dry climate over the region. The dry period lasts until mid-to-late June and ends with the arrival of a monsoon front accompanying a strengthened subtropical high, monsoonal winds, and anticyclonic upper-level vorticity in southeast Korea [32]. Deep convective systems associated with monsoon stationary fronts are frequently observed and cause heavy rainfall during Changma. The mean duration of Changma is about a month and Changma ends when the monsoon front moves northward. After Changma, the Korean Peninsula is affected from hot and humid air mass associated with the westward expansion of subtropical high. During this period, the heavy rainfall tends to come from isolated deep convection due to high CAPE.

Rather than using these climatological dates for the onset and retreat of the Changma phenomenon, this study uses each year's actual onset and retreat dates reported in the monthly weather bulletin by Korea Meteorological Administration (KMA) to define Changma and post-Changma period. Raining clouds for Changma were selected between onset and retreat dates for each year. Post-Changma rain events were considered from four days after Changma retreat date till the end of August, ensuring separation between the weather regimes. 
The Changma rainfall region is assumed to be confined to the vicinity of the stationary Changma front, as described in the KMA's bulletin. Therefore, longitude was limited to between $120^{\circ}$ and $135^{\circ} \mathrm{E}$. Post-Changma raining events for this study are confined within $32-39^{\circ} \mathrm{N}$ in latitude and $120^{\circ}-135^{\circ} \mathrm{E}$ in longitude.

The paper [34] divides the Meiyu season into the Meiyu and break periods and compared convective structures of precipitation features during the Meiyu, break, pre-Meiyu, and post-Meiyu period based on TRMM 3B42 and precipitation feature date base. In this study, we adopted a similar approach but applied it to Changma using TRMM PR profiles.

\section{Thermodynamic Environments}

This section investigates the effects of the thermodynamic environments on the formation of raining clouds during Changma and post-Changma periods, using 16-year (1998-2013) averaged MERRA reanalysis data. To examine the large-scale convective potential during summer, the joint frequency distribution with the axes of CAPE and CIN was constructed from the all data points collected over the study domain for each period, using 3-hourly MERRA reanalysis data. In general, CAPE represents the positive buoyancy of an air parcel and is an indicator of moist convective instability throughout the troposphere. It increases mostly due to an increase in boundary-layer specific humidity and temperature. An atmosphere with a low $(<1000 \mathrm{~J} / \mathrm{kg})$ and a moderate (1000-2500 J/kg) amount of CAPE can develop into weak and moderate convection, respectively. Strong convections are likely to occur with a high CAPE $(>2500 \mathrm{~J} / \mathrm{kg})$. Meanwhile, CIN measures the unlikelihood of thunderstorm development. However, it does not imply that the presence of CIN completely inhibits thunderstorm development. In general, atmospheres with a low amount of CIN $(<50 \mathrm{~J} / \mathrm{kg})$ can be easily broken by surface heating and with a moderate amount of CIN (50-200 J/kg) by strong heating or synopticscale forcing.

The analysis was done for three different periods, preChangma, Changma, and post-Changma period. For convenience, the frequency numbers are normalized by the number of total data points in the two-dimensional domain for each period, and then the summer mean values are subtracted from the period. The three periods present how favorable the environment is to convective activity during summer. The frequency anomaly distributions are displayed in Figure 1. The pre-Changma observations show distinct negative anomalies along the CAPE axis and distinct positive anomalies along the CIN axis. The period has relatively small CAPE with large CIN, compared to other periods. Overall, the thermodynamic environment tends to preclude the development of convective clouds. During the Changma period, positive anomalies are broadly located in the whole domain, while negative anomalies are shown in the area near the axis of CAPE where CIN is very small $(\sim 100 \mathrm{~J} / \mathrm{kg})$. Accordingly, lifting an air parcel should be able to overcome CIN energy and produce the buoyancy required for free convection. Accordingly, it seems to be difficult for convective clouds to develop without forcing mechanisms to lift an air parcel up to the level of free convection (LFC). The postChangma data shows distinct positive anomalies along the CAPE axis and negative anomalies along the CIN axis. The area of moderate-to-large CAPE values (300-4000 J/kg) and very small CIN values $(\sim 100 \mathrm{~J} / \mathrm{kg})$ exhibits large positive anomalies. In particular, the largest frequency exists in the range of a very small amount of CIN $(<50 \mathrm{~J} / \mathrm{kg})$ and a smallto-moderate amount of CAPE $(700-2000 \mathrm{~J} / \mathrm{kg})$. The small CINs can be easily broken by surface heating without any strong lifting mechanism. Hence, most convective clouds developed in the range might be weak to moderately strong. Thus, the thermodynamic environment in the post-Changma period is more favorable to the development of convective clouds. In the Changma period it is likely to be involved with a lifting mechanism to break the moderate-to-strong amount of CIN.

To examine the relative roles of the seasonally varying Level of Free Convections (LFCs) in the development of convective clouds, the two-dimensional frequency distribution for CAPE and LFC was plotted (Figure 2). The pre-Changma regime exhibits a narrow area of strong positive anomalies along the LFC axis and weak negative anomalies elsewhere. The positive area corresponds to low-to-high LFCs and very small CAPEs. That implies that the air parcels in the preChangma period tend to grow into relatively weak convective clouds due to the relatively high LFCs and small CAPEs. The Changma period shows positive anomalies in the LFC range of $800 \sim 500 \mathrm{hPa}$ and a wide range of CAPEs, but centered in the lower CAPEs. Large negative anomalies in the LFCs below $800 \mathrm{hPa}$ suggest that atmospheric environments in the period discourage the development of convective clouds. The positive anomalies during the post-Changma period coincide with low LFCs and moderate-to-large CAPEs. This signifies that even weak lifting mechanisms can overcome the low CINs shown in Figure 1 and lift up air parcels above the low LFCs. Then the high CAPEs tend to propel air parcels into deep convections. Thus, the post-Changma period has the most favorable atmospheric environments for vigorous convective cloud developments.

\section{Rainfall Characteristics as Seen in PR}

This section examines physical properties of raining clouds observed by TRMM PR, particularly vertical structure of clouds, rain rate, and cloud top height, for both Changma and post-Changma periods. All radar reflectivity profiles are either convective or stratiform, and then a contoured frequency-by-altitude-diagram (CFAD) analysis [35] is conducted (Figure 3). For convective rain type, the numbers of total PR data profiles in the two periods are 27439 and 44052, respectively. In the analysis, the frequency at each altitude is normalized by the total number of profiles, rather than by the number of observations greater than the certain $\mathrm{dBZ}$ at each altitude. For this reason, the frequency distribution in the figure is relative. During the Changma period, the CFADs in convective clouds have a distinct occurrence in the range between 17 and $30 \mathrm{dBZ}$ and between 5.5 and $8 \mathrm{~km}$ altitude. In 


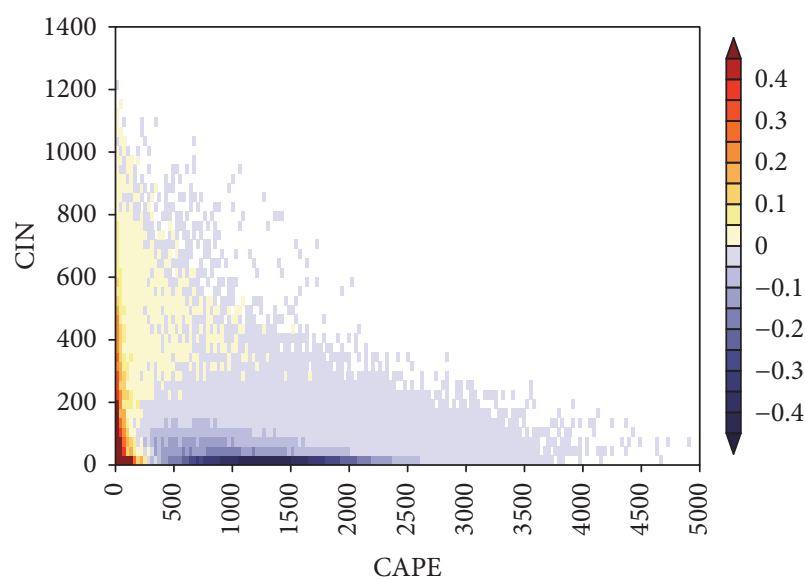

(a)

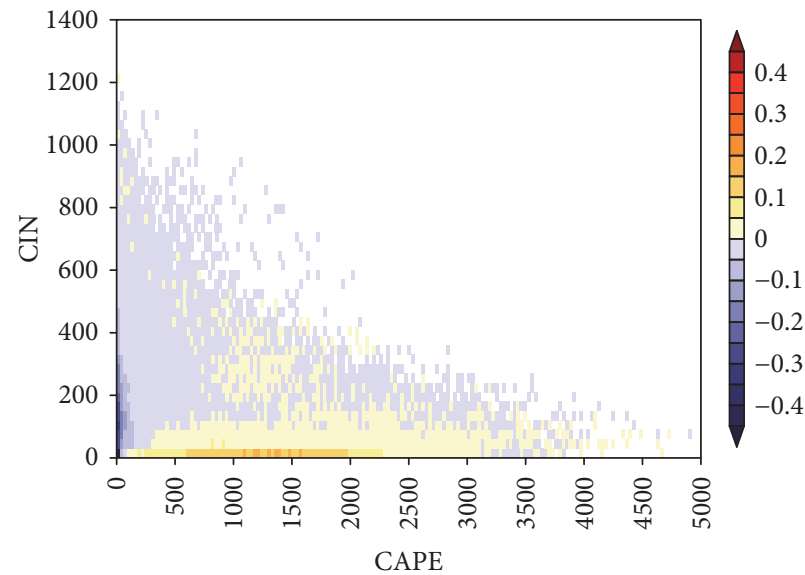

(c)

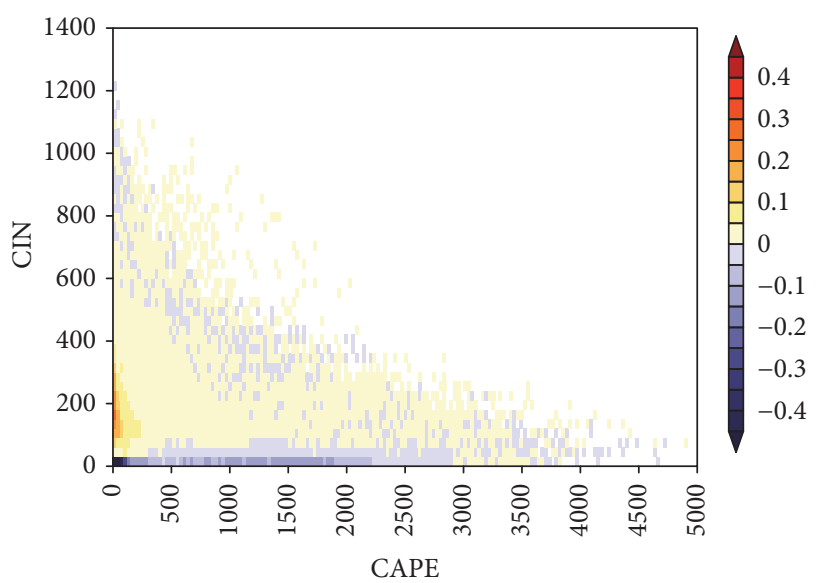

(b)

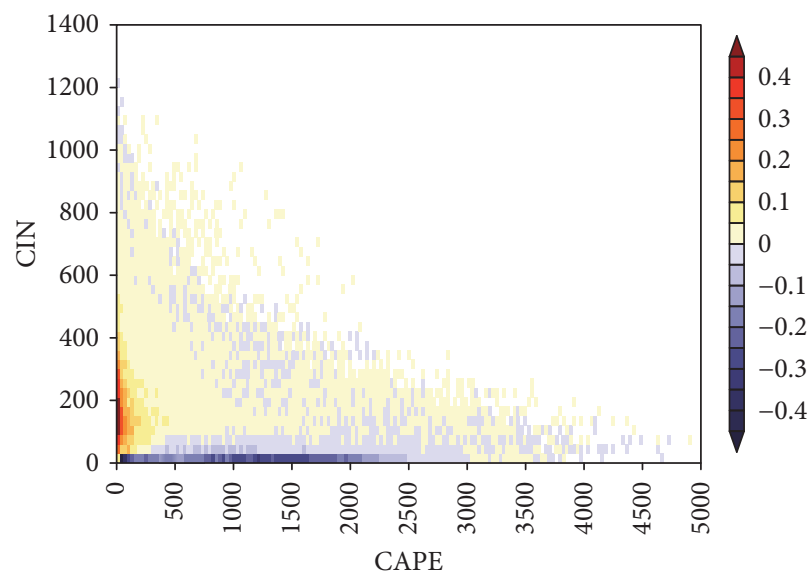

(d)

FIGURE 1: Anomalous joint probability density functions of CAPE and CIN based on 3-hourly MERRA reanalysis for (a) pre-Changma period, (b) the period during Changma, and (c) post-Changma period, and (d) difference between (b) and (c). Anomalies are calculated based on summer mean distribution.

other words, the period favors moderately deep convective clouds, relative to the spectrum of all convective clouds. This tendency disappears during the post-Changma period. Rather, above freezing level the radar reflectivities are spread across a broad range. Below freezing level, shallow convective clouds seem to occur more frequently, showing two distinct maxima in the frequency. However, their mean profiles of linear radar reflectivity between the two periods resemble each other. In fact, since mean radar reflectivity values tend to reflect some large radar reflectivity values when taking the average of the linear radar reflectivity, the median value of each level should also be examined. At lower levels, the median profile of the Changma period is several $\mathrm{dBZ}$ stronger than that of the post-Changma period, while above or around freezing level the median reflectivities are zero since radar reflectivities above freezing level often occur below the minimum detectable $\mathrm{dBZ}$ of $\mathrm{PR}(\sim 17 \mathrm{dBZ})$. Therefore, the median values are computed again only for radar reflectivities greater than the minimum detectable $\mathrm{dBZ}$. The two profiles show that in the rain layer the Changma period is $\sim 1 \mathrm{dBZ}$ stronger than the post-Changma period, and at other levels they match. Overall, the analyses for each period suggest that the Changma rainfall systems produce slightly stronger rain layers and dominant occurrences around $20 \mathrm{dBZ}$ at upper levels, while the post-Changma rainfall systems generate weaker shallow convective clouds and radar reflectivities in a broad range of $\mathrm{dBZ}$ at upper levels. In stratiform rain clouds, both periods show very similar characteristics to those in convective rain clouds. Overall, the mean and median of radar reflectivity profiles in the Changma period are $\sim 1 \mathrm{dBZ}$ stronger than the post-Changma period in the rain layer.

For convective rain clouds, the accumulated frequency distribution of the PR-derived rain rates for both periods is plotted in Figure 4(a). During the post-Changma period, relatively low rain intensity occurs more frequently. For instance, for the total accumulation of 70\%, the Changma and post-Changma period correspond to $9.5 \mathrm{~mm} / \mathrm{h}$ and $7.5 \mathrm{~mm} / \mathrm{h}$, respectively. For $90 \%$ accumulations, they are $28.5 \mathrm{~mm} / \mathrm{h}$ and $23.5 \mathrm{~mm} / \mathrm{h}$, respectively. Considering the whole range of rain intensity, the Changma rain events lead to stronger rain rates, while the post-Changma events lead toward lower rain rates. The mean intensities for the two periods are $10.6 \mathrm{~mm} / \mathrm{h}$ and 


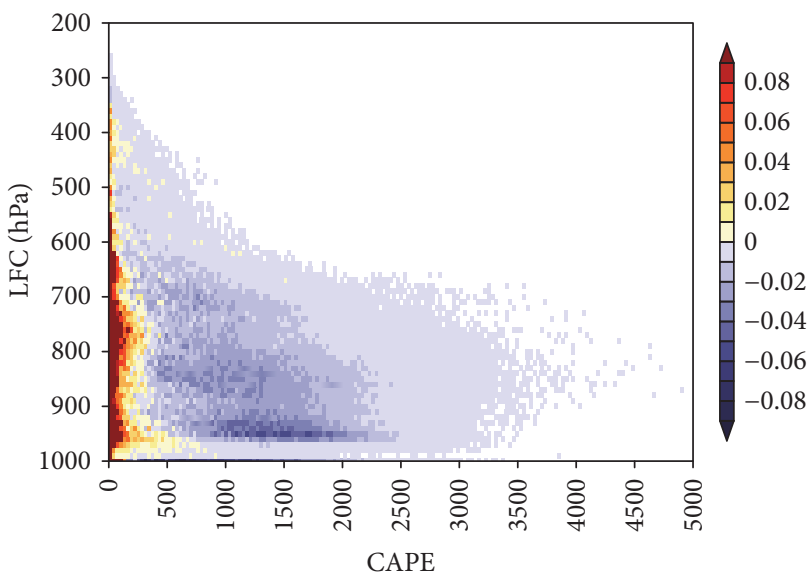

(a)

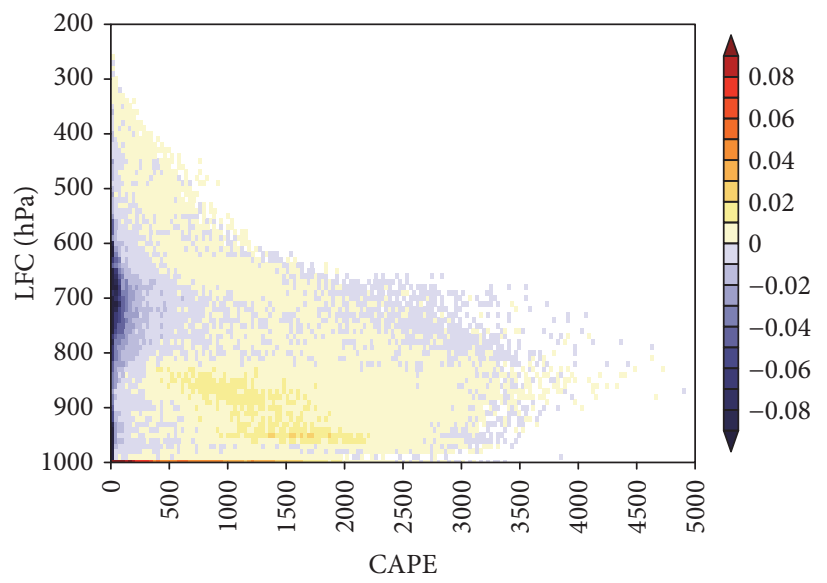

(c)

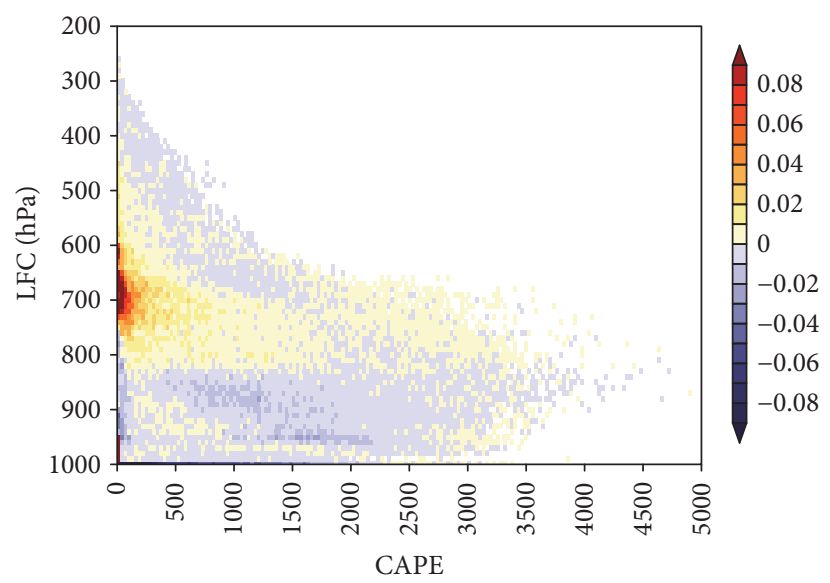

(b)

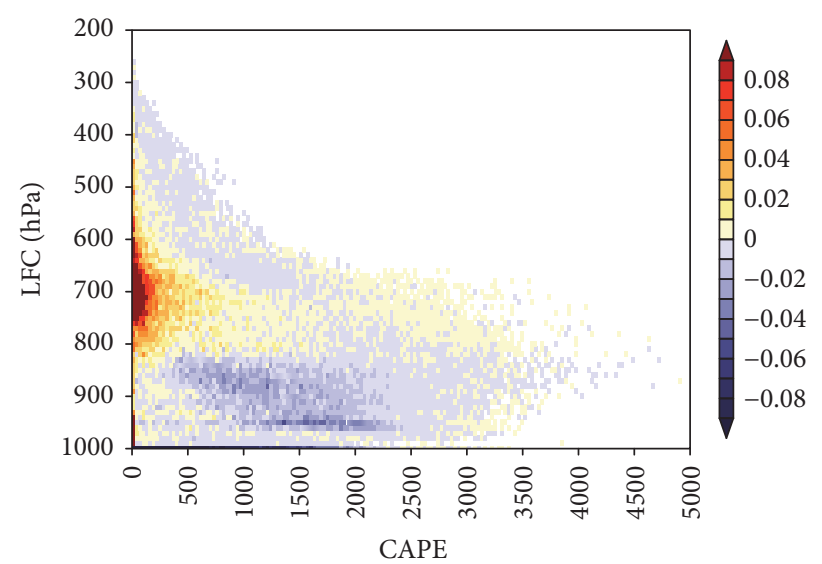

(d)

FIgURE 2: The same as Figure 1 except for CAPE and LFC.

$8.9 \mathrm{~mm} / \mathrm{h}$, respectively. The Changma period has an approximately $20 \%$ higher rain intensity than the post-Changma period. This is consistent to the higher median radar reflectivity at low levels observed in the Changma period. For the top $10 \%$ of rain intensity, there is still a difference of $5.4 \mathrm{~mm} / \mathrm{h}$ between the Changma and post-Changma periods, corresponding to $51.0 \mathrm{~mm} / \mathrm{h}$ and $44.6 \mathrm{~mm} / \mathrm{h}$, respectively. Overall, the Changma period has a distinct tendency to generate more intense rain compared to the post-Changma period.

Like the rain intensity analysis, the relative frequency distribution of the cloud top heights is displayed in Figure 4(b). Both periods exhibit bimodal distributions in height, whose maximum peaks are located around the altitude of $\sim 2.5 \mathrm{~km}$ and $\sim 5 \mathrm{~km}$. In particular, the post-Changma events form shallow convective clouds with the cloud top height around $2.8 \mathrm{~km}$ altitude more often than around $5 \mathrm{~km}$ altitude. It can be speculated that warm rain processes are more dominant during the post-Changma period. This suggests likelihood for rain of a light intensity can be attributed to the frequent development of the shallow convections. This feature is also addressed in the CFADs of radar reflectivity in Figure 3. On the other hand, the Changma rain events exhibit equivalent amplitudes at both $2.5 \mathrm{~km}$ and $5.5 \mathrm{~km}$ altitudes. Thus, the period yields a greater chance of convective clouds with higher cloud top height compared to the post-Changma period. The feature is well reflected in the frequency of rain rate and the CFADs of radar reflectivity, which has a larger frequency between $5 \mathrm{~km}$ and $8 \mathrm{~km}$ altitude, as shown in Figure 3. Therefore, it can be suggested that weak convective clouds appear to be filtered to a certain degree by the relatively large CINs, which should be overcome by fairly strong lifting forcing mechanisms. It is known that the cloud top height has a close relationship with rain intensity. For the two periods, the relationship between rain rate and cloud top height for different rain type and different period is further examined in the frequency of occurrences in the space of height and rain rate (Figure 5). As cloud top height increases, rain rate generally increases. The rain intensity of a few $\mathrm{mm} / \mathrm{h}$ is likely to come mostly from shallow convective clouds with cloud top height of $2-3 \mathrm{~km}$ in altitude of convective rain type. In particular, clouds with the height of $\sim 8 \mathrm{~km}$ are likely to generate a rain intensity of $\sim 10 \mathrm{~mm} / \mathrm{h}$ but are also able to generate any rain intensity in the whole range of rain rate. In the relationship plot, the Changma rain events tend to have larger frequency values toward higher rain rate for a given 

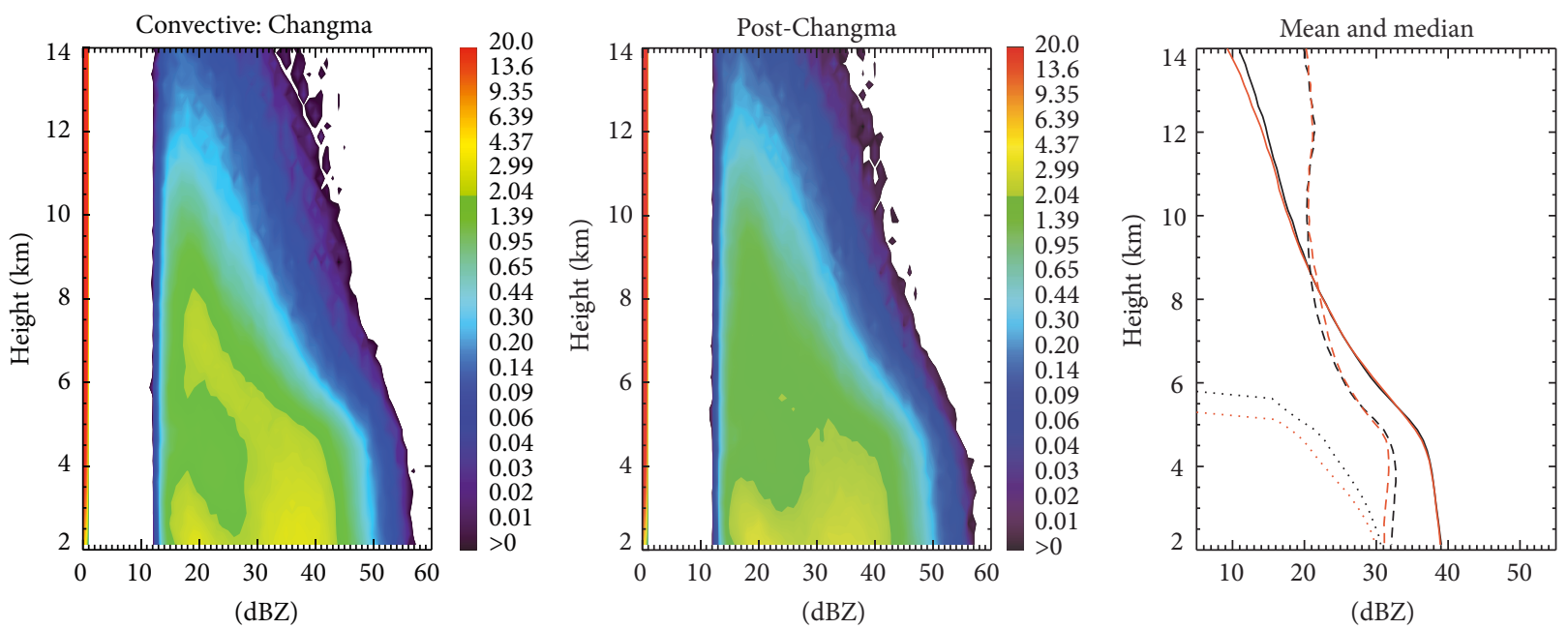

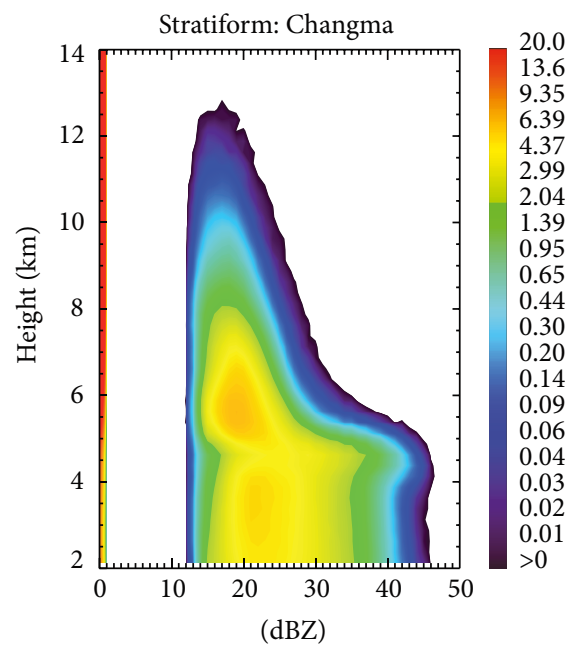

(a)

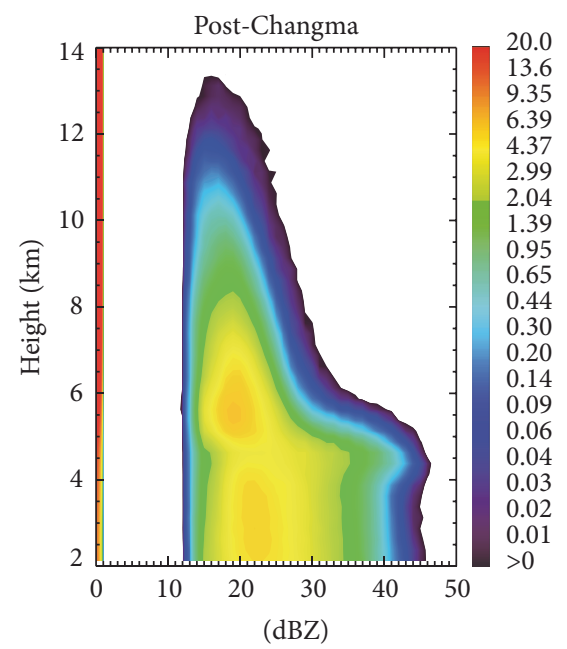

(b)

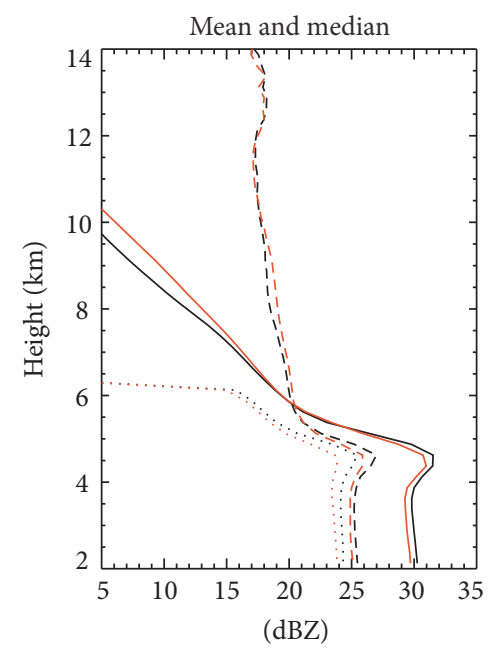

(c)

FIGURE 3: CFADs of the radar reflectivity profiles observed by PR ( $a, b)$ and mean radar reflectivity profiles (solid lines), median radar reflectivity profiles (dotted lines), and median profiles for radar reflectivities greater than the minimum detectable dBZ (dashed lines) (c). Black and red lines represent Changma and post-Changma period, respectively. The first and second rows represent convective and stratiform rain types, respectively.

altitude. On the other hand, more intense rain correlates positively to higher cloud top height in the post-Changma events, compared to the Changma events. Meanwhile, the estimation of rain rate from only cloud top height in tall storms, common in IR algorithms, seems to be more challenging than from low cloud top heights. In stratiform rain clouds, for relatively low rain rates there is a better relationship with cloud top height than in convective rain clouds. Otherwise, the relationship shows a very similar trend to that in convective rain clouds. Therefore, rain intensity for a given cloud top height is quite different depending on rain types. The IR algorithms might be improved by classifying rain types.

Although the thermodynamic environments illustrate relatively less favorable conditions for convective cloud development during the Changma period, the moderately deeper convective clouds and stronger rain intensity take place relatively more frequently within the whole convective clouds for each period.

\section{Composite Analysis of PR Rain}

To examine climatological evolution of rain-related PR variables in time, the 16-year JJA observations in the domain of interest $\left(30-36^{\circ} \mathrm{N}\right.$ in latitude and $120^{\circ}-132^{\circ} \mathrm{E}$ in longitude) are collected for each Julian day for rainy PR pixels. The variables are then averaged over the domain to produce the daily time series of the domain-averaged variables. Figure 6(a) displays the convective and stratiform fractions, which combined come close to $100 \%$. The sum is less than $100 \%$ because of an additional rain category besides the two categories in the $2 \mathrm{~A} 23$ products of $\mathrm{PR}$. The stratiform fraction can be obtained by subtracting the convective fraction from $100 \%$. In early June, the convective fraction is less than or near $10 \%$ and then increases gradually to $25 \%$ until late July. During August, between 213 and 243 in Julian days, it remains around $\sim 25 \%$. On the other hand, as the convective fraction increases the stratiform fraction decreases from $\sim 90 \%$ to $\sim 75 \%$. That is, 

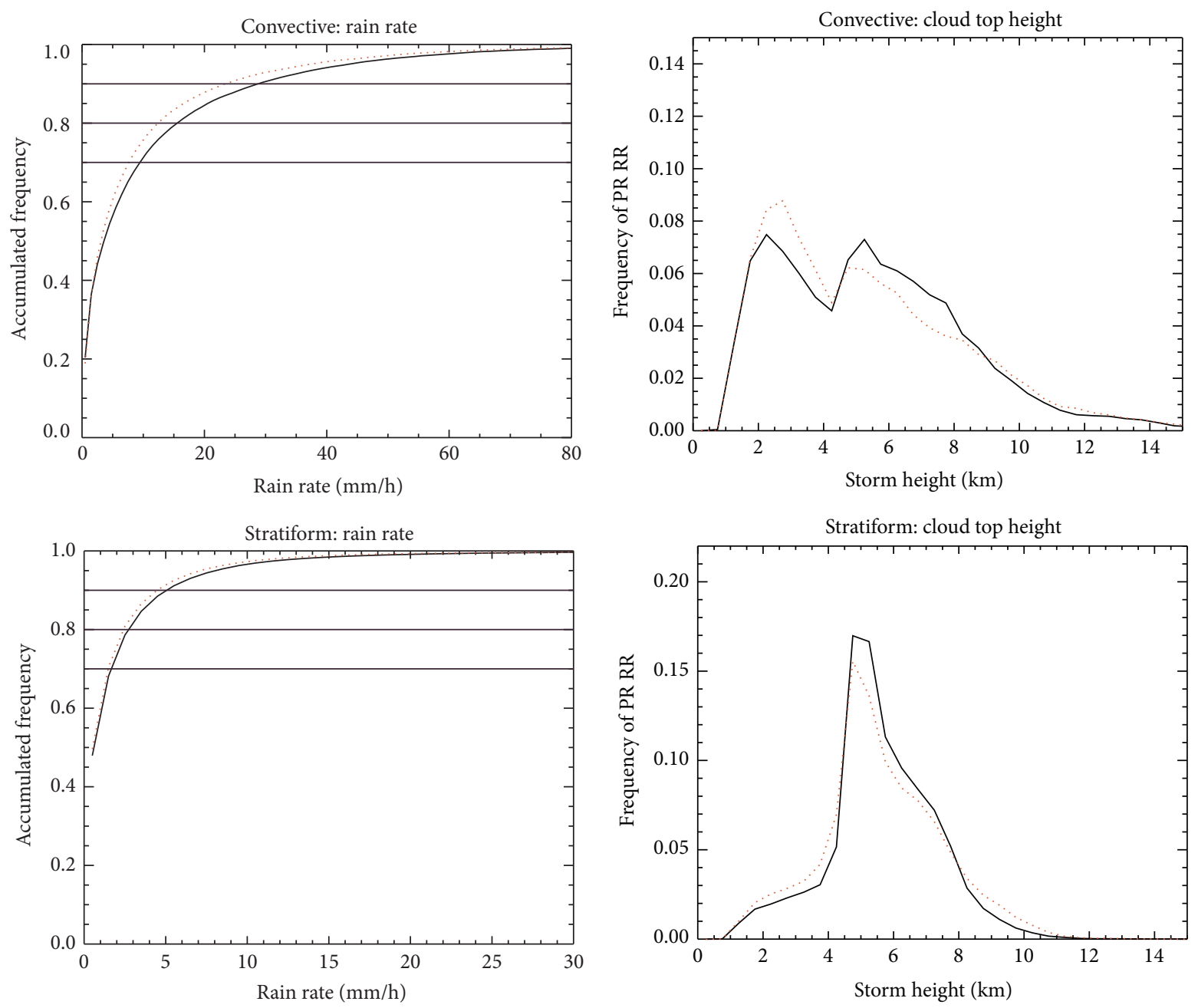

(a)

(b)

FIGURE 4: Accumulated frequency distribution of rain rate (a) and relative frequency distribution of cloud top height (b) for convective and stratiform rain clouds. Black and red lines represent Changma and post-Changma period, respectively.

for rainy pixels as observed by the PR instrument there is a larger chance of convective rain during the latter half of JJA. Thus, convective activities within rainfall systems appear more vigorous during the period, although the Changma front moves further northward. For clarity, the total number of rain pixels for each rain type is plotted similarly to the fraction plot. As shown in Figure 6(b), the population of stratiform rain events increases rapidly during the preChangma period and then decreases drastically toward the end of the Changma period, while the population of the convective rain events increases gradually and then stays during August. Accordingly, the convective fraction becomes larger during the post-Changma period (Figure 6(a)). The figure indicates that although rain events during August are more likely to be of a convective rain type, they are not necessarily vigorously convective in terms of the population for a given day.

Figure 6(c) shows the temporal trend of mean cloud top height is plotted for each rain type. As the Changma front approaches, the domain-averaged convective cloud top height dramatically increases and then decreases more or less gradually. This strongly suggests the Changma front raises convective clouds to higher altitude than any other period of JJA. During the Changma period, stationary fronts overcome the relatively large amount of $\mathrm{CIN}$, generating relatively taller convective clouds (Figures 3 and 4). This can be supported by the study of [36]. According to the study, the baroclinicity during Changma periods is strengthened compared to the whole summer, being associated with the occurrence of the Changma front and the main portion of precipitation over the Korean Peninsula is accompanied with enhanced baroclinicity north of the rainfall area. Therefore, a lifting mechanism in association with the Changma front seems to play an important role in enhancing raining systems during the Changma period. During the post-Changma period, since the surface and atmosphere become warmer, the small CIN seems to be easily broken without strong lifting mechanisms, producing shallow cumuli with a large 

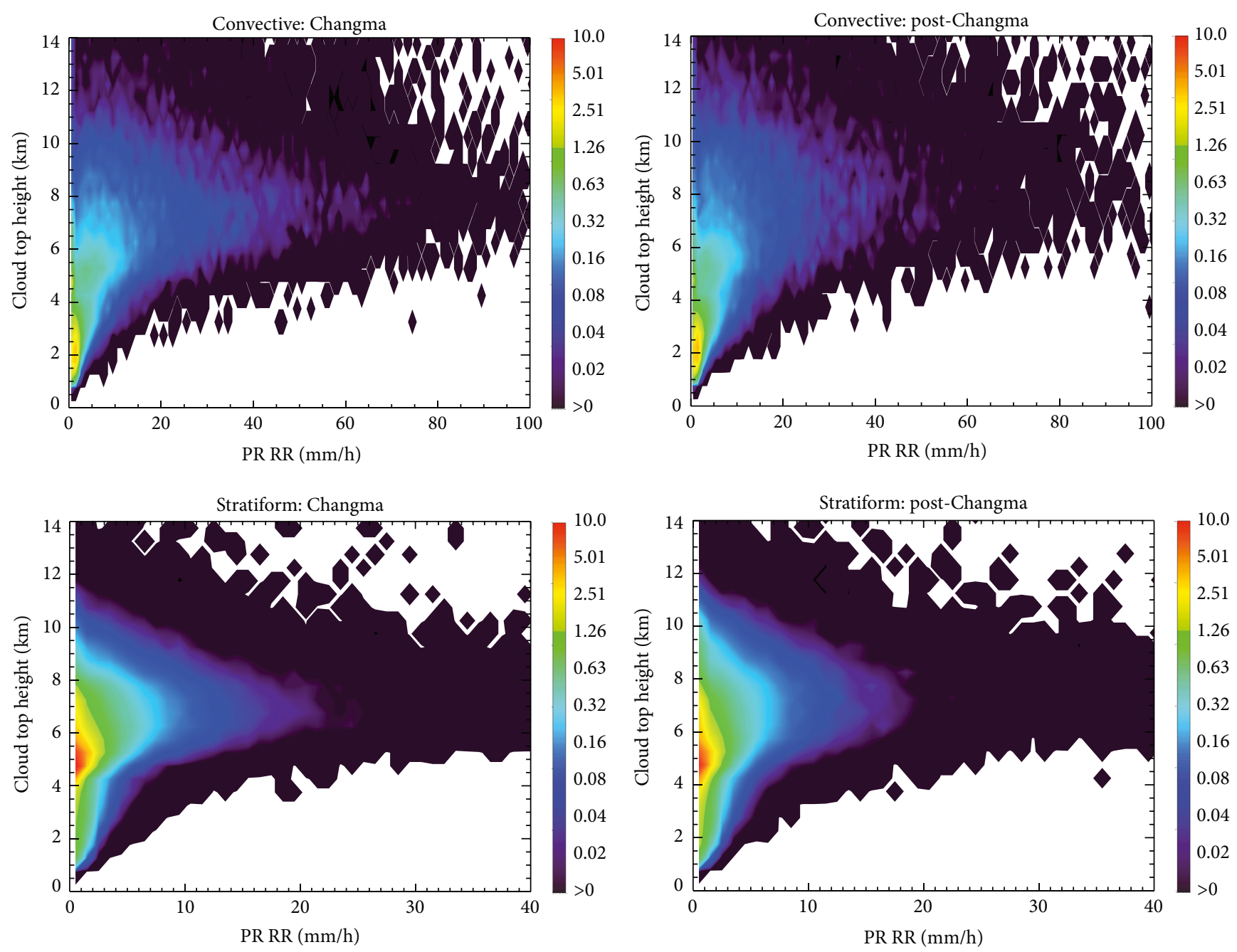

FIGURE 5: Relative frequency distribution of occurrences (\%) as a function of PR rain rate and cloud top height.

frequency of cloud top height around $2.8 \mathrm{~km}$ altitude (Figures 3 and 4). On the other hand, the mean height for the stratiform rain type stays high even during the post-Changma front period.

For contrast with the domain-averaged variables, this analysis takes a zonal average for each Julian day and latitude bin for the 16-year data set and then subtracts the domain-averaged value. Figure 7 shows the climatological propagation of the variables in the 2 -dimensional space with time and latitude. The JJA rain-related climatology shows a distinct northward propagation in time. The strong activity of convective rain systems associated with the Changma front starts in early June near $23^{\circ} \mathrm{N}$ latitude and then moves northward during June to mid-July in the upper-left corner of Figure 7(a). Until late August, activity diminishes in the domain since the rainfall systems associated with the Changma front move north beyond $35^{\circ} \mathrm{N}$ in latitude. Again, the convective rain events in a bin of 1 day and $1^{\circ}$ latitude occur more often near the Changma front than any other JJA period over the region of interest (Figures 6(b) and 7(a)). The rain durations shown in Figure 7 (a) are consistent with the climatological period of Changma. In late August the convective activity appears in the northeast corner of the domain, moving southward. This seems to be the so-called secondary Changma period. Although there are distinct rain events in the area, the secondary Changma is briefly in the domain, compared to the duration of post-Changma period.

Furthermore, stratiform rain events are more common during the same periods (Figure $7(\mathrm{~b})$ ). In other words, rainfall events feature active convective rain clouds trailing with broad regions of stratiform rain clouds. This is clearly seen in the total amount of rain and mean rain intensity of each rain type (Figure 8). In fact, the Changma front generates both a larger amount of rain and stronger rain intensity for both convective and stratiform rain types. Overall, for convective clouds along the Changma front, the rain intensity is much stronger and the cloud top height is much higher than during any other JJA period (Figures 8 and 9). However, the convective fraction is lower than that of any other periods, while the stratiform fraction is higher. This indicates that stratiform rain clouds develop more often than convective clouds. Although abundant stratiform rain 


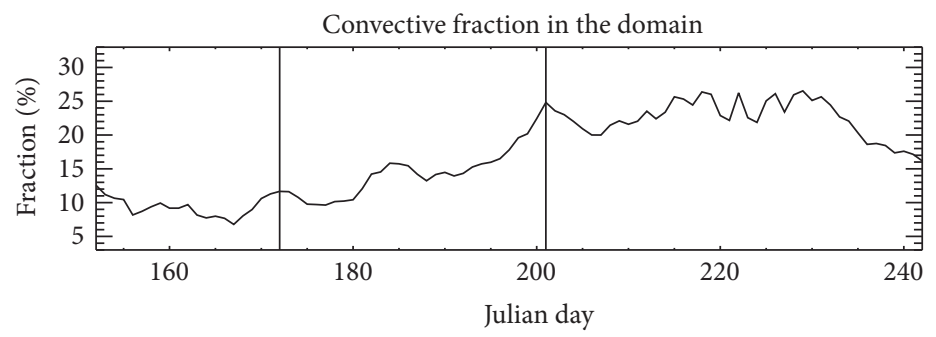

(a)

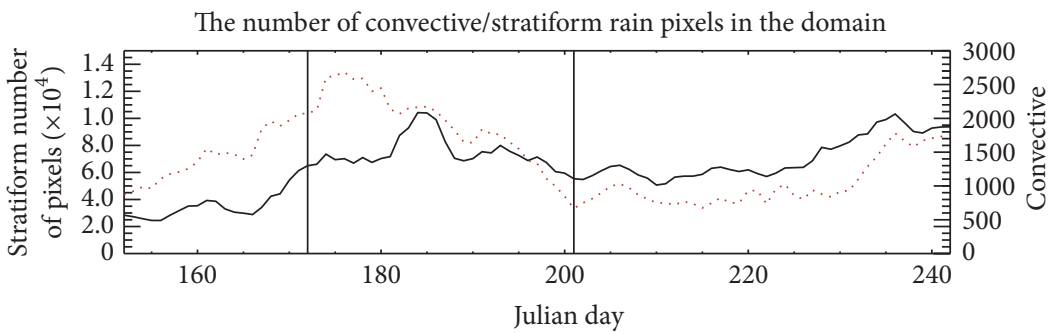

(b)

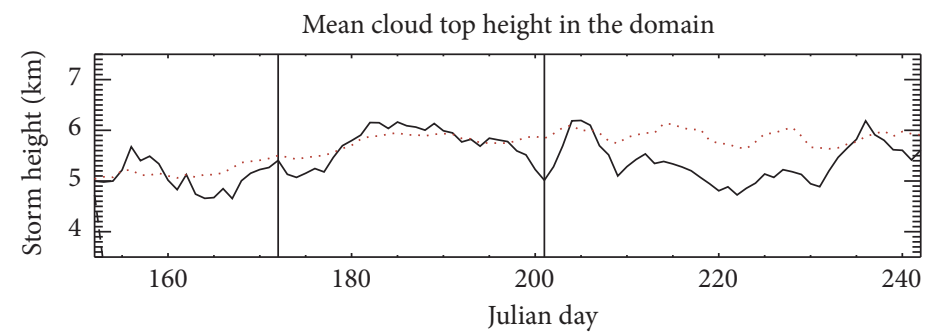

(c)

Figure 6: Climatological evolution of (a) convective fraction, (b) the number of convective and stratiform rain pixels, and (c) mean cloud top height in time (Julian day). The two vertical lines represent the beginning and end dates of the climatological period for Changma. Solid and dotted lines represent convective and stratiform rain clouds, respectively.

$\langle$ The number of convective rain pixels $\rangle$ minus $\langle$ domain-averaged value $(=234.5)\rangle$

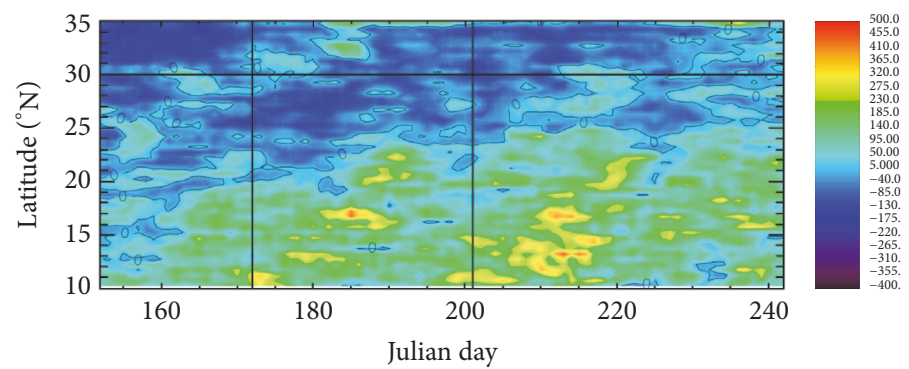

(a)

$\langle$ The number of stratiform rain pixels $\rangle$ minus $\langle$ domain-averaged value $(=772.5)\rangle$

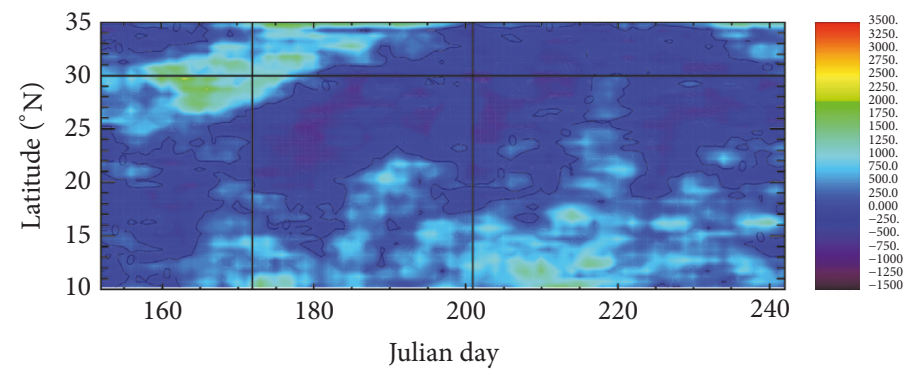

(b)

Figure 7: Climatological anomaly propagation of the number of rain pixels for (a) convective and (b) stratiform rain types in the 2dimensional space with time (Julian day) and latitude. The two vertical lines represent the climatological onset and retreat dates of Changma. 


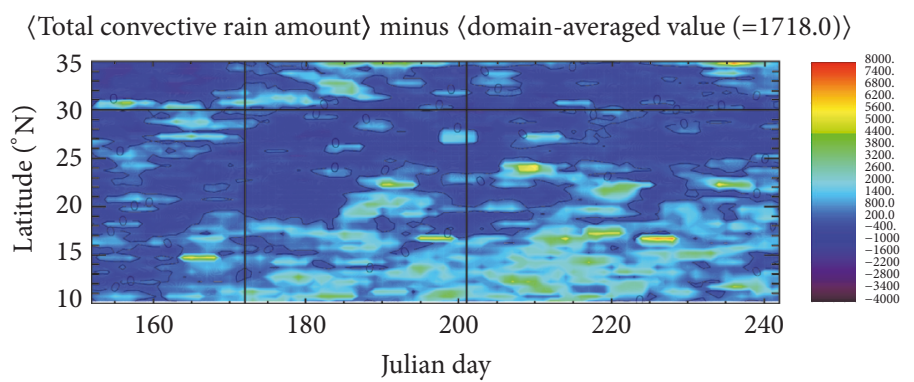

(a)

$\langle$ Total stratiform rain amount $\rangle$ minus $\langle$ domain-averaged value $(=1715.1)\rangle$

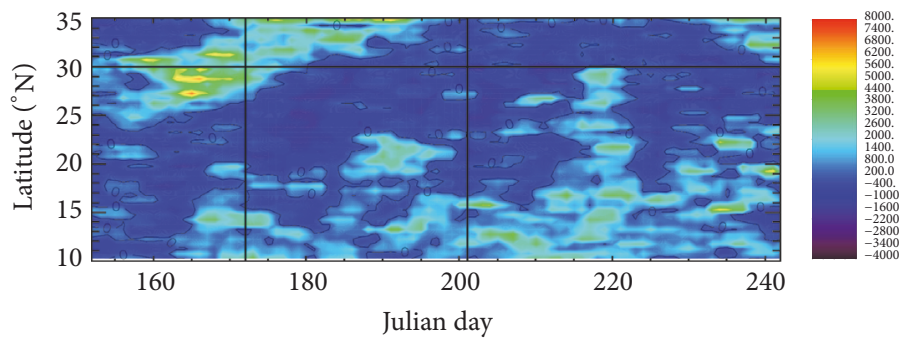

(b)

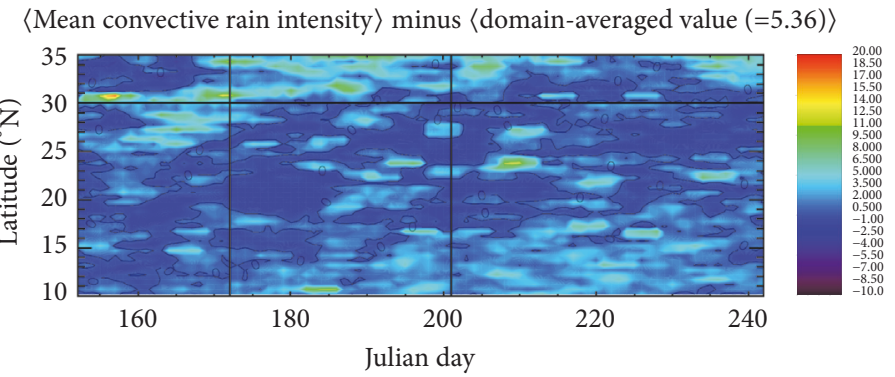

(c)

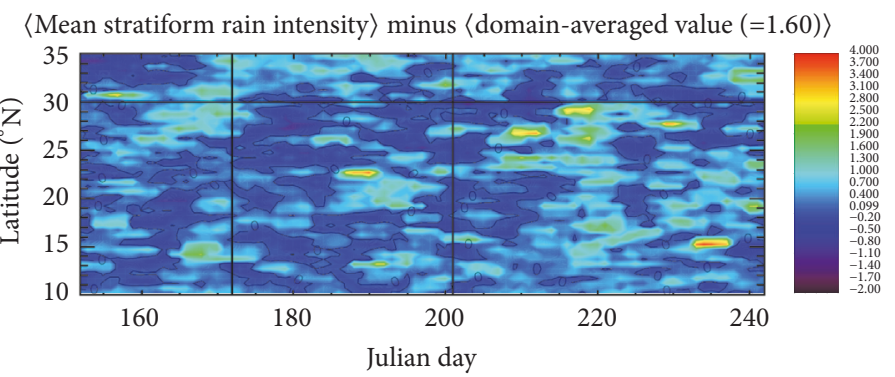

(d)

FIGURE 8: Climatological anomaly propagation of the total rain amount for (a) convective and (b) stratiform rain clouds and of mean rain intensity for (c) convective and (d) stratiform rain clouds in the 2-dimensional space with time (Julian day) and latitude. The two vertical lines represent the beginning and end dates of the climatological period for Changma.

clouds develop during the period, their rainfall characteristics are very similar to those in other JJA periods in terms of rain intensity and cloud top height. This suggests that convective rain clouds have a larger seasonal variability than stratiform rain clouds even during summer. The seasonal variability in convective rain type seems to be closely associated with the thermodynamic environments shown in CAPE and CIN and LFC and the dynamic environments associated with systematic forcing mechanisms such as the Changma front.

\section{Conclusions}

Changma, a summertime monsoon phenomenon over the Korean Peninsula, has considerable socioeconomic impact every year, bringing about half of annual rainfall events and more than half of total annual rainfall. Previous studies investigated the large-scale dynamic and thermodynamic atmospheric environment of Changma using reanalysis grid data and conventional observations. This study focuses on 
$\langle$ Mean convective cloud top height $\rangle$ minus $\langle$ domain-averaged value $(=3.98)\rangle$

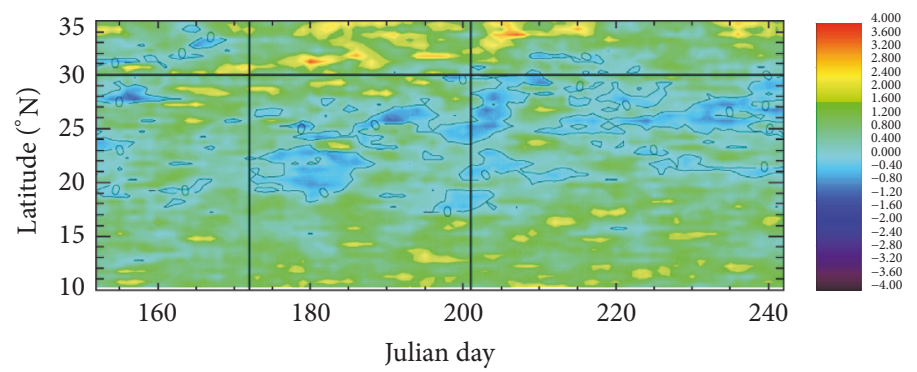

(a)

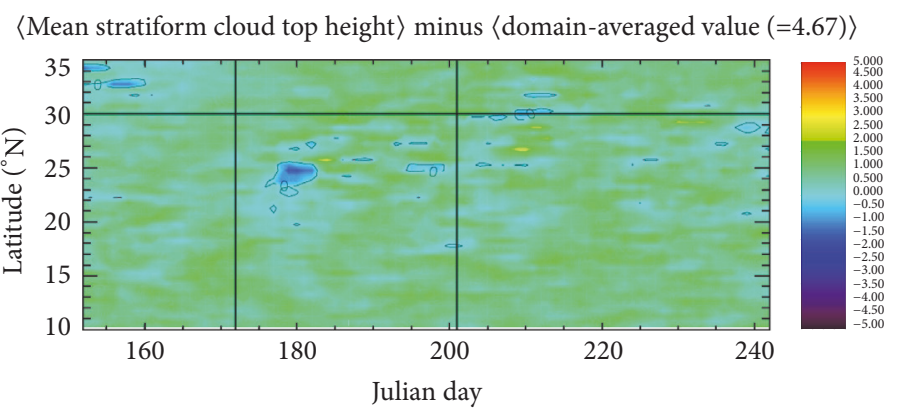

(b)

FIGURE 9: Climatological anomaly propagation of mean cloud top height for (a) convective and (b) stratiform rain clouds in the 2-dimensional space with time (Julian day) and latitude. The two vertical lines represent the climatological onset and retreat dates of Changma.

climatological properties of rain clouds generated during the Changma period using the 16-year data sets of the PR of the TRMM satellite, augmented with reanalysis data. Additional analysis focuses on post-Changma clouds and then compares them over the East Asian region $\left(10^{\circ} \mathrm{N}-40^{\circ} \mathrm{N}, 122^{\circ} \mathrm{E}-134^{\circ} \mathrm{E}\right)$. This provides additional insight into the characteristics of raining clouds during the period.

The effects of the large-scale atmospheric environments on the formation of rain clouds are investigated. The largescale convective potential is examined based on a joint frequency distribution, with dimensions of CAPE and CIN, using 3-hourly MERRA reanalysis data. The Changma regime shows fairly large CAPEs and moderate-to-large CINs, compared to the post-Changma period. Air parcel lifting must overcome the environmental CIN energy to produce the buoyancy required for free convection. On the other hand, post-Changma has moderate-to-large CAPEs and very small CINs. The CFADs of CAPE and LFC also exhibit high LFCs during the Changma period. Since atmospheric environments in the Changma period discourage convection, strong lifting forcing mechanisms need to exist for convective cloud development.

Physical properties of raining clouds observed by TRMM PR are also examined. During the Changma period the CFADs of PR profiles in convective clouds show a large frequency in the range within 17-30 dBZ, and within $5.5-8 \mathrm{~km}$ altitude. In other words, the Changma period favors moderately deep convective clouds, relative to the spectrum of all convective clouds. During the post-Changma period, shallow convective clouds seem to dominate, compared to the
Changma period. However, this does not necessarily mean deep and strong convective clouds never develop during the post-Changma period. When considering the whole range of rain intensity, the Changma rain events favor strong rain rate, while the post-Changma events favor low rain rate, with mean values of $10.6 \mathrm{~mm} / \mathrm{h}$ and $8.9 \mathrm{~mm} / \mathrm{h}$, respectively. The mean intensity for the Changma period is approximately $20 \%$ higher than that for the post-Changma period. This is consistent with the higher median radar reflectivity at low levels observed in the Changma period. For the top $10 \%$ of rain intensity, there is still a difference of $5.4 \mathrm{~mm} / \mathrm{h}$ between Changma and post-Changma periods, corresponding to $51.0 \mathrm{~mm} / \mathrm{h}$ and $44.6 \mathrm{~mm} / \mathrm{h}$, respectively. Hence, the Changma period has a distinct tendency to generate more intense rain than the post-Changma period.

Both periods display bimodal distributions in cloud top heights, whose maximum peaks are located around $2.5 \mathrm{~km}$ and $5 \mathrm{~km}$ altitude. In particular, the post-Changma events form shallow convective clouds with the cloud top height around $2.8 \mathrm{~km}$ altitude more frequently than around $5 \mathrm{~km}$. This suggests the preference for light rain intensity is due to the relatively frequent development of shallow convection. During the Changma period, to a certain degree shallow convective clouds appear to be filtered by the relatively large CINs.

In the frequency relationship between rain rate and cloud top height, Changma events tend to favor higher rain rate for a given altitude. On the other hand, more intense rain correlates positively to higher cloud top height in postChangma events. Overall, for convective clouds along the 
Changma front, the rain intensity is much stronger and the cloud top height much higher than any other JJA period. On the other hand, stratiform rainfall characteristics during the Changma period are very similar to those in other JJA periods in terms of rain intensity and cloud top height. This indicates that convective rain clouds have a larger seasonal variability than stratiform rain clouds even during summer.

Although the thermodynamic environments imply less favorable conditions for convective cloud development during the Changma period, for convective clouds migrating along the Changma (stationary) front, the rain intensity is much stronger and the cloud top height is higher than during any other summer period The seasonal variability in rain parameters related to convective rain type appears to result from thermodynamically and dynamically different environments during summer.

\section{Conflicts of Interest}

The authors declare that there are no conflicts of interest regarding the publication of this paper.

\section{Acknowledgments}

TRMM data was provided by NASA Goddard Earth Sciences Data and Information Services Center. This research has been supported by a research grant from Kongju National University in 2014.

\section{References}

[1] D.-K. Lee, H.-R. Kim, and S-Y. Hong, "Heavy rainfall over Korea during 1980-1990," Korean Journal of the Atmospheric Sciences, vol. 1, no. 1, pp. 32-50, 1998.

[2] K.-H. Seo, J.-H. Son, S.-E. Lee, T. Tomita, and H.-S. Park, "Mechanisms of an extraordinary East Asian summer monsoon event in July 2011," Geophysical Research Letters, vol. 39, no. 5, 2012.

[3] K.-H. Seo, J.-H. Son, and J.-Y. Lee, "A new look at Changma," Atmosphere, vol. 21, no. 1, pp. 109-121, 2011.

[4] K.-J. Ha, K.-S. Yun, J.-G. Jhun, and C.-K. Park, "Definition of onset/retreat and intensity of Changma during the boreal summer monsoon season," Asia-Pacific Journal of Atmospheric Sciences, vol. 41, no. 6, pp. 927-942, 2005.

[5] M.-A. Kim, B.-H. Heo, K.-E. Kim, and D.-I. Lee, "Analysis of Kinematic characteristics of synoptic data for a heavy rain event (25 June 2006) occurred in Changma front," Atmosphere, vol. 19, no. 1, pp. 37-51, 2006.

[6] T. Enomoto, B. J. Hoskins, and Y. Matsuda, "The formation mechanism of the Bonin high in August," Quarterly Journal of the Royal Meteorological Society, vol. 129, no. 587, pp. 157-178, 2003.

[7] K. Ninomiya and T. Akiyama, "Multi-scale Features of Baiu, the Summer Monsoon over Japan and the East Asia," Journal of the Meteorological Society of Japan. Ser. II, vol. 70, no. 1B, pp. 467495, 1992.

[8] K.-J. Ha and S.-S. Lee, "On the interannual variability of the Bonin high associated with the East Asian summer monsoon rain," Climate Dynamics, vol. 28, no. 1, pp. 67-83, 2007.
[9] K.-J. Ha, S.-K. Park, and K.-Y. Kim, "Interannual variability in summer precipitation around the korean peninsula and its associated East Asian summer circulation," Asia-Pacific Journal of Atmospheric Sciences, vol. 39, no. 5, pp. 575-586, 2003.

[10] J.-S. Park, J.-G. Jhun, and E.-J. Lee, "Characteristic large-scale circulation anomalies associated with persistent features of extreme precipitation over northeast Asia from premonsoon season to monsoon season," Journal of Geophysical Research Atmospheres, vol. 114, no. 11, Article ID D11108, 2009.

[11] I.-S. Kang, "Relationship between El-Nino and Korean climate variability," Asia-Pacific Journal of Atmospheric Sciences, vol. 34, pp. 390-396, 1998.

[12] Z. Wu, B. Wang, J. Li, and F.-F. Jin, "An empirical seasonal prediction model of the east Asian summer monsoon using ENSO and NAO," Journal of Geophysical Research, vol. 114, no. D18, 2009.

[13] D.-Y. Gong, J. Yang, S.-J. Kim et al., "Spring arctic oscillationEast Asian summer monsoon connection through circulation changes over the western North Pacific," Climate Dynamics, vol. 37, no. 11-12, pp. 2199-2216, 2011.

[14] S.-E. Lee and K.-H. Seo, "The development of a statistical forecast model for changma," Weather and Forecasting, vol. 28, no. 6, pp. 1304-1321, 2013.

[15] B. Wang, J.-G. Jhun, and B.-K. Moon, "Variability and singularity of Seoul, South Korea, rainy season (1778-2004)," Journal of Climate, vol. 20, no. 11, pp. 2572-2580, 2007.

[16] M. H. Kwon, J.-G. Jhun, B. Wang, S.-I. An, and J.-S. Kug, "Decadal change in relationship between east Asian and WNP summer monsoons," Geophysical Research Letters, vol. 32, no. 16, Article ID L16709, 2005.

[17] C.-H. Ho, J.-Y. Lee, M.-H. Ahn, and H.-S. Lee, "A sudden change in summer rainfall characteristics in Korea during the late 1970s," International Journal of Climatology, vol. 23, no. 1, pp. 117-128, 2003.

[18] I.-S. Kang, C.-H. Ho, Y.-K. Lim, and K.-M. Lau, "Principal modes of climatological seasonal and intraseasonal variations of the Asian summer monsoon," Monthly Weather Review, vol. 127, no. 2-3, pp. 322-340, 1999.

[19] K.-J. Lee, K.-Y. Heo, A.-S. Suh, J.-S. Park, and K.-J. Ha, "Application of images and data of satellite to a conceptual model for heavy-rainfall analysis," Atmosphere, vol. 20, pp. 131151, 2010, (Korean).

[20] S. Moon, K.-J. Ha, M. Moon, J.-G. Jhun, and J.-Y. Moon, "Designing of conceptual models on Typhoon and Changma utilizing GK-2A satellite data," Atmosphere, vol. 26, no. 2, pp. 215-226, 2016.

[21] C. Kummerow, W. Barnes, T. Kozu, J. Shiue, and J. Simpson, "The tropical rainfall measuring mission (TRMM) sensor package," Journal of Atmospheric and Oceanic Technology, vol. 15, no. 3, pp. 809-817, 1998.

[22] C. Kummerow, Y. Hong, W. S. Olson et al., "The evolution of the Goddard profiling algorithm (GPROF) for rainfall estimation from passive microwave sensors," Journal of Applied Meteorology, vol. 40, no. 11, pp. 1801-1820, 2001.

[23] E.-K. Seo, "Characteristics of Summer Rainfall over East Asia as Observed by TRMM PR," Journal of the Korean Earth Science Society, vol. 32, no. 1, pp. 33-45, 2011.

[24] E.-K. Seo, "Rainfall characteristics in the tropical oceans: observations using TRMM TMI and PR," Journal of the Korean Earth Science Society, vol. 33, no. 2, pp. 113-125, 2012. 
[25] E.-K. Seo and M. I. Biggerstaff, "Regional variability within global-scale relations between passive microwave signatures and raining clouds over the tropical oceans," Journal of Applied Meteorology and Climatology, vol. 51, no. 5, pp. 897-911, 2012.

[26] T. Iguchi and R. Meneghini, "Intercomparison of singlefrequency methods for retrieving a vertical rain profile from airborne or spaceborne radar data," Journal of Atmospheric \& Oceanic Technology, vol. 11, no. 6, pp. 1507-1516, 1994.

[27] T. Iguchi, T. Kozu, R. Meneghini, J. Awaka, and K. I. Okamoto, "Rain-profiling algorithm for the TRMM precipitation radar," Journal of Applied Meteorology, vol. 39, no. 12, pp. 2038-2052, 2000.

[28] J. Awaka, T. Iguchi, and K. Okamoto, "Early results on rain type classification by the tropical rainfall measuring mission (TRMM) precipitation radar," in 8th URSI Commission Open Symposium, pp. 22-25, URSI, Aveiro, Portugal, 1998.

[29] M. M. Rienecker, M. J. Suarez, R. Gelaro et al., "MERRA: NASA's modern-era retrospective analysis for research and applications," Journal of Climate, vol. 24, no. 14, pp. 3624-3648, 2011.

[30] M. M. Rienecker, M. J. Suarez, R. Todling et al., “The GEOS-5 data assimilation system-documentation of versions 5.0.1 and 5.1.0, and 5.2.0," NASA Tech. Rep. Series on Global Modeling and Data Assimilation NASA/TM-2008-104606, vol. 27, 2008.

[31] B. Wang and X. Xu, "Northern Hemisphere summer monsoon singularities and climatological intraseasonal oscillation," Journal of Climate, vol. 10, no. 5, pp. 1071-1085, 1997.

[32] J.-E. Chu, S. N. Hameed, and K.-J. Ha, "Nonlinear, intraseasonal phases of the East Asian summer monsoon: Extraction and analysis using self-organizing maps," Journal of Climate, vol. 25, no. 20, pp. 6975-6988, 2012.

[33] H.-R. Byun, D.-K. Lee, and C.-H. Joung, "A study on the atmospheric circulation during the dry period before the Changma," Part I: Existence and characteristics, vol. 28, no. 2, pp. 71-88, 1992.

[34] W. Xu, E. J. Zipser, and C. Liu, "Rainfall characteristics and convective properties of Mei-Yu precipitation systems over South China, Taiwan, and the South China sea. Part I: TRMM observations," Monthly Weather Review, vol. 137, no. 12, pp. 4261-4275, 2009.

[35] S. E. Yuter, J. Stout, R. Wood, J. Kwiatkowski, and D. Horn, "Relative errors in TRMM satellite version 5 and version 6 products: Steps forward and backward," in Proceedings of the 32nd Conf. on Radar Meteorology, 5R.7, American Meteorological Society, Albuquerque, NM, USA, October 2005.

[36] H. Hübener, U. Ulbrich, and P. Speth, "The role of baroclinic instability for changma rainfall," Korean Journal of the Atmospheric Sciences, vol. 3, no. 2, pp. 53-66, 2000. 

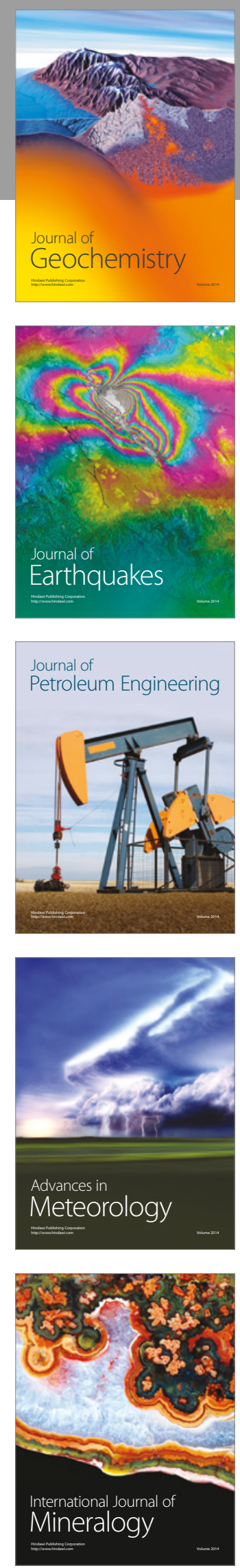
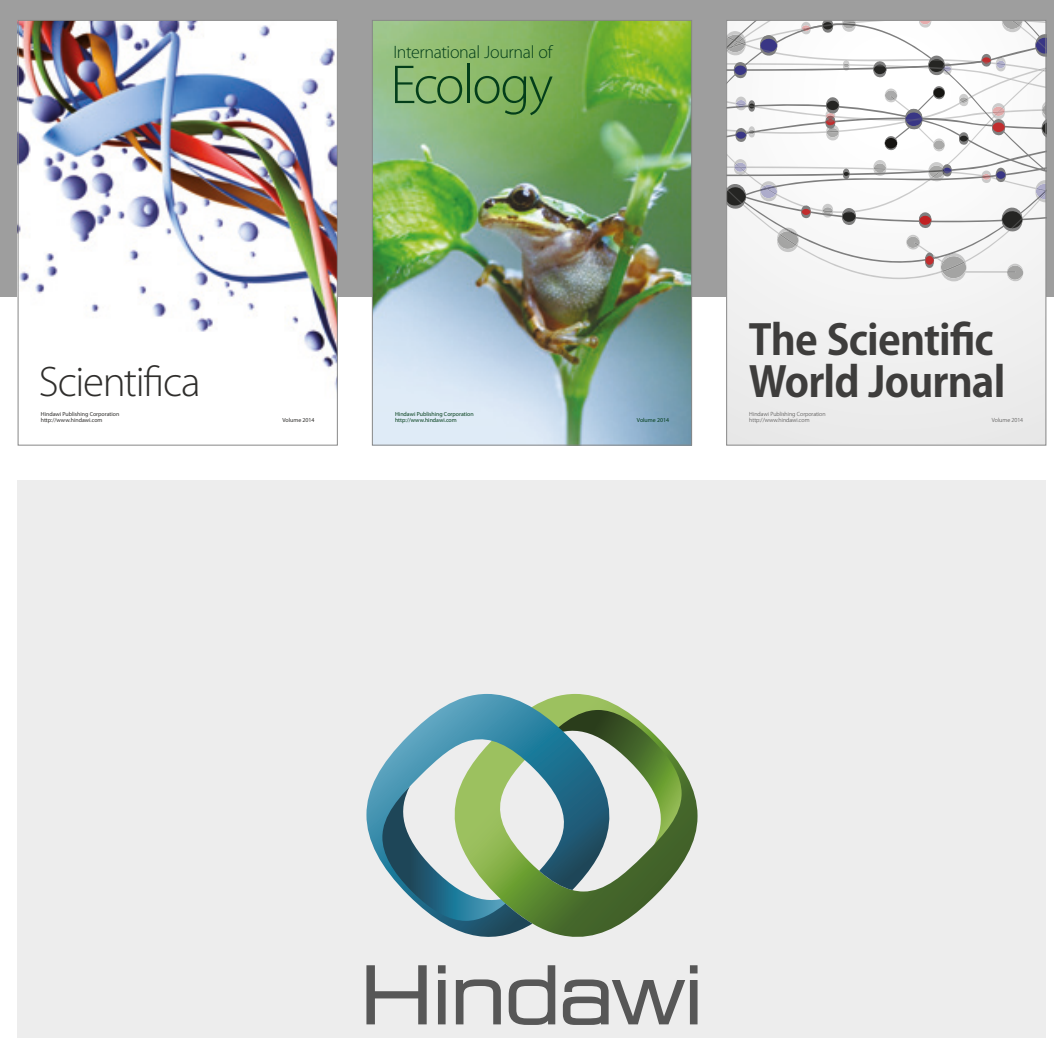

Submit your manuscripts at

https://www.hindawi.com
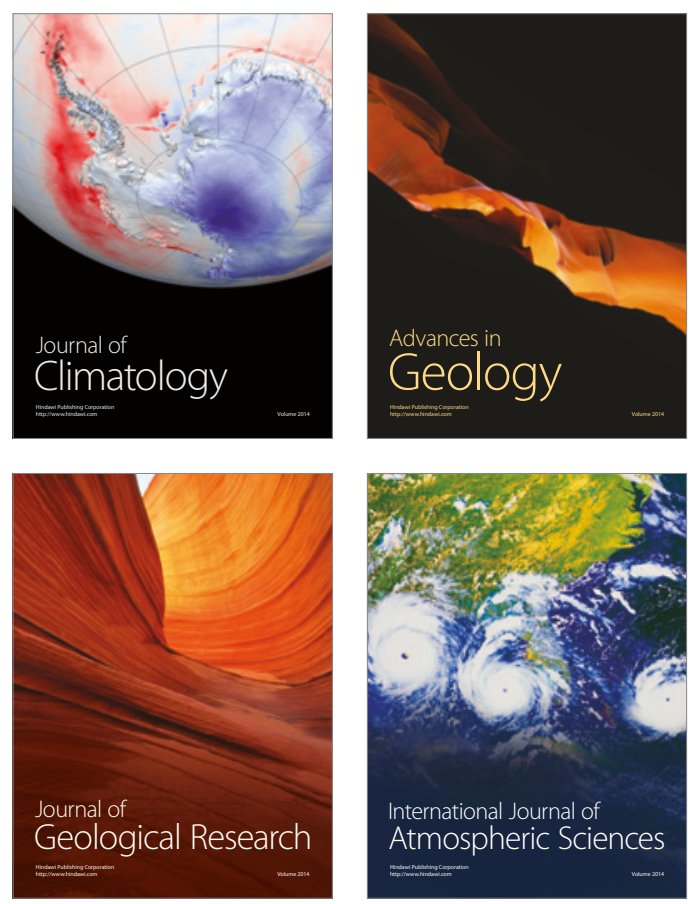

The Scientific

World Journal
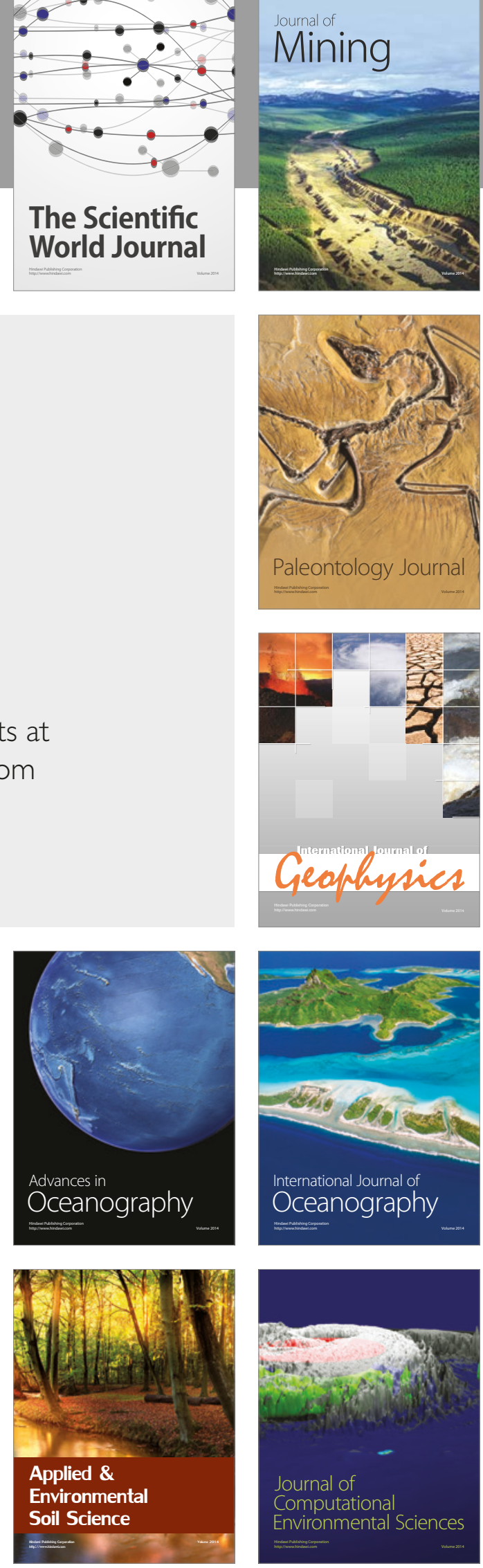